\title{
Analysis of Determinants that Influence on Development of the Participants Family of the BPJS Health Recipient Dues (PBI) in Balongrejo Village, Bagor Subdistrict, Nganjuk District
}

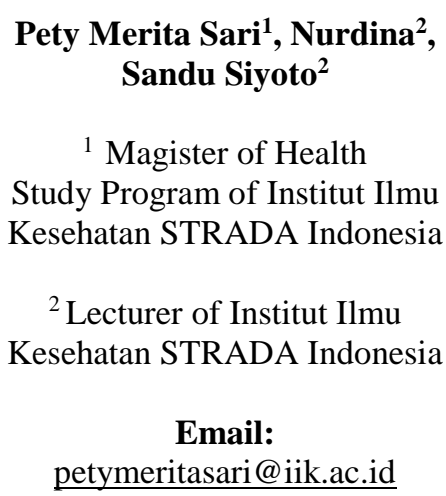

Received : October 12, 2019

Accepted : February 13, 2020

Published : May 11, 2020

\begin{abstract}
The toddler period is an important period to determine the quality of the future of the child during this time the development process runs quickly. One of the things we have to ask is the development of toddlers from poor families from the family of BPJS PBI. The purpose of this study was to analyze the factors that support the development of toddlers in the families of PBI BPJS participants in Balongrejo Village. The research design uses Cross sectional. The study population was all toddler in the BPJS PBI family in Ds. Balongrejo. With a sample of 106 respondents using the Simple Random sampling technique. Independent variables were nutritional status, food intake, infectious disease and knowledge. Dependent variable development of toddlers. The instrument uses questionnaire sheets and observation sheets, analyzed using Ordinal Regression test The results of the study are based on the ordinal regression test simultaneously all variables affect the development with the value of Sig. (2-tailed) $=0,000<0,05$, partially the history of infectious diseases and parental knowledge of children under five does not affect development with values. Sig $(2$-tailed $)=0.148>0.05$ and sig $(2$-tailed $)=0.996>0.05$, nutritional status and food intake influence the development with the Sig. (2-tailed) $=0,000<0,05$, nutritional status has a greater influence than food intake. Having a good nutritional status 1.3 times can have the opportunity to improve the development process of toddlers. Providing health education to mothers about the importance of fulfilling nutrition, development, and active posyandu activities can reduce developmental deviations of toddler.
\end{abstract}

Keywords: Developmental, toddler, nutritional status, food intake, infectious disease history, and parent knowledge 


\section{INTRODUCTION}

Within the framework of the Sustainable Development Goals targeted until 2030 it also targets one goal, namely the reduction of maternal and child health problems (Kemenkes, 2015). Maternal and child health problems that are still often found in developing countries like Indonesia are nutritional problems of children under five which have an impact on other health problems, especially for poor and poor families who receive assistance from the Social Assistance Beneficiary Agency (BPJS PBI) that needs attention specifically. Where these nutritional problems can affect the process of growth and development in infants, with the growth and development of children who are less than optimal can reduce the quality of human resources (Dian et al., 2014).

From data from the British Journal Of Nutrition (2013), overall 21\% of children aged 6-12 years in 4 countries, namely: Indonesia, Malaysia, Thailand and Vietnam have low body weight and 19\% have short bodies. From the data and information of the Ministry of Health in 2018 the number of children under the age of 1-4 years in Indonesia in 2017 reached 19,101,845, of which 3.8\% under five had poor nutrition, and 14\% of Indonesian toddlers experienced malnutrition. Whereas for the number of toddlers in East Java in 2017 reached 2,302,731 and is the largest contributor to the toddler population after West Java, of that $2.9 \%$ under five had poor nutrition and $12.6 \%$ of children under five experienced malnutrition, from the data East Java Province is one of the provinces with a high number of nutritional problems with a prevalence rate of $26.1 \%$ from the national figure of $27.5 \%$ (Dinkes Provinsi Jatim, 2016), while for the Human Development Index data as a benchmark for the quality of human resources in East Java Province is $69,74 \%$ below the national figure of $70.18 \%$ with this number East Java ranked 14th out of 34 Provinces in Indonesia (Badan Pusat Statistik, 2017). The coverage of the APBN contribution recipient (PBI) is 14,874,630 (38.06\%) and the Regional Budget PBI is 608,950 (1.56\%) (Profil Dinkes Provinsi Jatim, 2017).

The period of children under five years old (toddlers) is an important period to determine the quality of the future of children where during this time the process of growth and development runs fast, both physical, cognitive, skills, social, emotional including personality development (Sulistyorini and Rahayu, 2017 ) To achieve good growth and development, adequate nutrition is needed in order to achieve good toddler nutritional status (Gladys et al., 2011). Therefore, special attention is needed from parents so that the process runs as optimally as possible, in addition to nutritional intake factors there are external factors that can affect the development of toddlers.

Nganjuk Regency is one of the 100 Priority Districts / Cities for intervention in nutritional problems in Indonesia for 2017 and 2018 (TNP2K, 2017). Nganjuk Regency is ranked number 3 out of 38 Regencies / Cities in East Java province, where the most prevalent malnutrition is found where good nutritional status is the basis of health that can affect immunity, vulnerability to disease, and growth and physical and mental development (I Gusti \& Indraguna, 2017).

Based on this background, this study was conducted to determine the factors that influence the development of children under five in the families of BPJS Beneficiary Beneficiary (PBI) participants in Balongrejo Village, Bagor District, Nganjuk Regency.

\section{METHODS}

This study used a cross sectional research design. The population and sample of this study were all toddlers in the families of PBI BPJS participants in Balongrejo Village, Bagor District, Nganjuk Regency. By using the Simple Random sampling technique, the sample size is 106 respondents. The independent variables in this study are nutritional status, food intake, history of infectious diseases and knowledge and the dependent variable in this study is the development of toddlers. The instruments used in this study were questionnaire sheets and observation sheets, analyzed using Ordinal Regression tests 
RESULT

Characteristics Of Variable Food Intake

Table 1. Variable Characteristics based on toddler food intake in family BPJS PBI in Balongrejo Village, Bagor District, Nganjuk Regency

\begin{tabular}{ccc}
\hline Food Intake & Frequenci & Percent(\%) \\
\hline Well & 39 & 36,8 \\
\hline Moderate & 32 & 30,2 \\
\hline Less & 35 & 33 \\
\hline Total & 106 & 100
\end{tabular}

From the table can show that almost half of the respondents had good food intake with a percentage of $36.8 \%$ as many as 39 toddlers.

Table 2. Variable Characteristics based on toddler Infectious Deseases in family BPJS PBI in Balongrejo Village, Bagor District, Nganjuk Regency

\begin{tabular}{llcc}
\hline No & $\begin{array}{c}\text { Infectious } \\
\text { Deseases }\end{array}$ & Frequenci & Percent(\%) \\
\hline 1 & Infectious & 28 & 26,4 \\
\hline 2 & Non Infectious & 78 & 73,6 \\
\hline & Total & 106 & 100 \\
\hline
\end{tabular}

From the table can show that most of the respondents had never experienced an infection with a percentage of $73.6 \%$ as many as 78 toddlers.

Table 3. Variable Characteristics based on toddler Nutritional status in family BPJS PBI in Balongrejo Village, Bagor District, Nganjuk Regency

\begin{tabular}{cccc}
\hline No & Nutritional status & Frequenci & Percent(\%) \\
\hline 1 & Overweight & 5 & 4,7 \\
\hline 2 & Normal & 38 & 35,8 \\
\hline 3 & Underweight & 43 & 40,6 \\
\hline 4 & Defisit & 20 & 18,9 \\
\hline \multicolumn{2}{r}{ Total } & 106 & 100 \\
\hline
\end{tabular}

From the table can show that most of the respondents have good nutritional status with a percentage of $51.9 \%$ as many as 55 respondents.

Table 4. Variable Characteristics based on toddler Development in family BPJS PBI in Balongrejo Village, Bagor District, Nganjuk Regency

\begin{tabular}{llcc}
\hline No & Development & Frequenci & Percent $(\boldsymbol{\%})$ \\
\hline 1 & Appropriate & 55 & 51,9 \\
\hline 2 & Hesitate & 22 & 20,8 \\
\hline 3 & Deviate & 29 & 27,4 \\
\hline & Total & 106 & 100
\end{tabular}

From the table can show that most of the respondents have toddler development in appropriate with the percentage of $51.9 \%$ as many as 55 respondents. 
Table 5. Variable Characteristics based on toddler Knowladge in family BPJS PBI in Balongrejo Village, Bagor District, Nganjuk Regency

\begin{tabular}{cccc}
\hline No & Knowladge & Frequenci & Percent $(\%)$ \\
\hline 1 & Good & 29 & 27,4 \\
\hline 2 & Moderate & 39 & 36,8 \\
\hline 3 & Less & 38 & 35,8 \\
\hline & Total & 106 & 100
\end{tabular}

From the table can show that half of the respondents have enough knowledge level with a percentage of $36.8 \%$ as many as 39 respondents.

\section{Test Ordinal Regression Statistics}

Table 6. Ordinal regression test table by combining nutritional status, food intake, disease infection and knowledge of toddler development in the family participation of BPJS (BPI) aid recipients in Balongrejo Village, Bagor District, Nganjuk Regency

\begin{tabular}{lrrrr}
\hline Model & \multicolumn{2}{c}{ Log Likelihood Chi-Square } & df & Sig. \\
\hline Intercept Only & 159.040 & & & \\
\hline Final & 84.708 & 74.333 & 4 & .000 \\
\hline
\end{tabular}

Link function: Logit.

From the table can show the results of statistical tests simultaneously using Ordinal Regression were obtained on all variables, namely nutritional status, food intake, history of infectious diseases and parents' knowledge of the toddler had an influence on the development of infants with a sig value $=$ $0,000(\mathrm{p}<\mathrm{a}=0.05)$.

Table 7. Ordinal regression test table partially determines nutritional status, food intake, history of infectious diseases and parental knowledge of toddlers on the development of toddlers in the family participation of BPJS beneficiaries (BPI) in Balongrejo Village, Bagor District, Nganjuk Regency

Std.

95\% Confidence Interval

\begin{tabular}{|c|c|c|c|c|c|c|c|}
\hline & & Estimate Error & Wald & df & Sig. & Lower Bound & Upper Bound \\
\hline \multirow[t]{2}{*}{ Threshold } & {$[$ Development $=1]$} & 4.6931 .471 & 10.183 & 1 & .001 & 1.811 & 7.575 \\
\hline & [Development $=2]$ & 6.5931 .579 & 17.432 & 1 & .000 & 3.498 & 9.688 \\
\hline \multirow[t]{4}{*}{ Location } & Nutritional status & $1.321 \quad .361$ & 13.363 & 1 & .000 & .613 & 2.030 \\
\hline & Food Intake & $\begin{array}{ll}1.234 \quad .410\end{array}$ & 9.046 & 1 & .003 & .430 & 2.037 \\
\hline & Infectious Deseases & $\begin{array}{ll}-.996 \quad 688 \\
\end{array}$ & 2.093 & 1 & .148 & -2.345 & .353 \\
\hline & Knowledge & $\begin{array}{ll}-.002 & .392\end{array}$ & .000 & 1 & .996 & -.771 & .767 \\
\hline
\end{tabular}

Link function: Logit.

The results of partial statistical tests using Ordinal Regression found that the variable nutritional status and food intake obtained the value of Sig. (2-tailed) $=0,000 \mathrm{P}<\mathrm{a}(0,05)$ then $\mathrm{H} 0$ is rejected. This means that $\mathrm{H} 1$ is accepted so that there is a significant influence between nutritional status and food intake on the development of toddlers. In the history of infectious diseases and knowledge, Sig. (2-tailed) = p > 0.05 , then $\mathrm{H} 0$ is accepted. This means that $\mathrm{H} 1$ is rejected so that there is no significant influence between the history of infectious diseases and knowledge of the development of children under five, from the results of these tests also found that nutritional status has a greater influence than food intake. Having a good nutritional status 1.3 times can have the opportunity to improve the development process of toddlers. Whereas having a good food intake can have the opportunity to improve the development process 1.2 times. 


\section{DISCUSSION}

\section{Nutritional status of toddlers in families PBI BPJS participants in Balongrejo Village, Bagor District, Nganjuk Regency}

From the results of the study it was found that out of 106 toddlers $27(25.5 \%)$ under five had malnutrition status and 19 (17.9\%) toddlers had poor nutritional status from the results of this study it can be concluded that almost half of the 106 toddlers experienced nutritional problems namely malnutrition and malnutrition by $46(43.4 \%)$ toddlers. From the results of this study it was found that $35.9 \%$ of children under five experienced abnormal development. From the results of statistical tests, it can be seen that nutritional status influences the development partially or simultaneously with a value of sig. $=0,000$ or smaller than the value of $\alpha=0.05(\mathrm{P}<\alpha)$, and by having a good nutritional status 1.3 times can opportunity to improve the development process of toddlers.

Toddlers in this study who experienced poor nutritional status and poor nutrition, their weight was below the yellow line and the red line which means that this indicates that the child has mild malnutrition and moderate to severe malnutrition. For their height they also experience a delay in growing where their height is not according to their age. Good nutritional status is the basis of health that can affect immunity, vulnerability to disease, and physical and mental growth and development (I Gusti \& Indraguna, 2017).

The results of this study are supported by the results of a study from Solihin, Faisal and Dadang (2013), which states that under nutritional status has an influence on the development of toddlers in Cibanteng Village, Bogor Regency, West Java. Toddlers who experience malnutrition or malnutrition tend to cause toddlers to lose their curiosity towards the environment so that they fail to achieve motoric and communication development compared to children who have good nutritional status. The motoric abilities of toddlers who are malnourished are lower as a result of the inhibition of the muscle maturation process so that the muscle's mechanical abilities are reduced.

\section{Food Intake of toddlers in families PBI BPJS participants in Balongrejo Village, Bagor District, Nganjuk Regency}

From the results of the study it was found that out of 106 toddlers $35(33 \%)$ toddlers had less food intake. The majority of the residents of Balongrejo Village are Farmers, the staple food there is rice with the most commonly eaten side dishes being tempeh and tofu. Most food consumption of toddlers is high in carbohydrates and low in protein, to consume vegetable foods they get from around the house from the vegetables they grow themselves. From the results of interviews that many mothers experienced difficulties, their children did not like to consume vegetables and when preparing food only obeyed the wishes of the child so that the child would eat, this could lead to the growth and development of the child becomes hampered. Food consumption that is not good enough in quality or quantity can cause problems of malnutrition and disorders in the development of children under five (Yusna et al., 2013).

Based on the results of this study, it can also be seen that $29(27.4 \%)$ of $35(33 \%)$ toddlers with food intake lacked deviant development, and the results of the relationship test that food intake was associated with toddler development. While from the results of statistical tests it can be seen that food intake has an effect on development partially with sig. $=0,000$. While the results of the simultaneous test with food intake have a OR that is smaller than the nutritional status, namely food intake has the opportunity to improve the development process of children under the age of 1.2 times. From the results of these studies it can be concluded that food intake is a less dominant factor that influences the development of children under five in this study. Food intake factor is a factor that is closely related to the nutritional condition of children which can ultimately affect nutritional status and if in the long term do not get attention will affect the child's development process.

If food intake for each toddler is reduced and often parents do not realize that the age of the toddler requires adequate food intake for growth and development. Especially toddlers who are in the family participation of PBJ BPJS that are included in poor families have a greater percentage of the problem of nutritional disorders than non BPJS PBI families.

The results of the research from Adi and Dini (2013), stated that low food intake can have an impact on the emergence of nutrition and health problems for household members, especially in 
vulnerable groups, including toddlers. In essence the impact of vulnerability in children under five is related to failure to thrive.

\section{History of infectious diseases of toddlers in families PBI BPJS participants in Balongrejo Village, Bagor District, Nganjuk Regency}

From the results of the study it was found that out of 106 toddlers $28(26.4 \%)$ toddlers had a history of infectious diseases. The results of this study can be concluded that a small proportion of respondents had a history of infectious diseases. In this study infectious diseases commonly experienced by toddlers are diarrhea, chickenpox, and respiratory disease. Chronic recurrent infections such as diarrhea, respiratory infections and fever increase the risk of malnutrition. Infection can cause weight loss through vomiting, diarrhea or decreased appetite. Infection of the gastrointestinal tract can also cause interference with digestion and absorb food. This certainly affects the number of calories the body can absorb. The number of calories is not able to meet the body's needs for activity and growth, this condition causes malnutrition. At this age toddlers are very susceptible to diseases such as diarrhea or ispa and fever, eventually can suffer from malnutrition and admire the development process.

From the results of this study it can also be seen that $22(20.8 \%)$ of $28(26.4 \%)$ toddlers who have a history of infectious diseases have a deviant development and from the results of statistical tests it can be seen that the history of infectious diseases has no influence on the development of infants with sig value $=0,148$ or greater than the value of $\alpha=0.05(\mathrm{P}>\alpha)$, From these data it can be concluded that the history of infectious diseases does not affect the development of infants.

The results of this study are in line with the research of Nakamori et al (2010) that infectious diseases do not affect the incidence of underweight due to the precautionary measures taken to prevent under-fives from getting underweight as through exclusive breastfeeding (Lestari, 2016).

Parents will make an effort such as checking their child if they experience illness to a health service, because they have not spent any more money on medical treatment because they have been covered by the government. The type of illness that most toddlers suffer from is cough diarrhea, runny nose, and fever and not for months. When toddlers are sick, parents will improve the quality of food intake given to toddlers in order to speed up the recovery of the toddler's condition. Although the level of education and income of parents of children under five is low. However, if parents have an attitude of prevention and good prevention of infectious diseases, this can be overcome.

Prevention factors are one of the important factors in inhibiting the spread of pain and death. Based on this, efforts are needed to overcome this problem, namely to improve the nutritional status of children through the fulfillment of nutritional intake for toddlers so that the immune system increases and is not susceptible to infectious diseases. Mothers play an important role in fulfilling toddlers' nutritional intake (Nurwijayanti, 2016).

\section{Parent Knowladge of toddlers in families PBI BPJS participants in Balongrejo Village, Bagor District, Nganjuk Regency}

From the results of the study it was found that out of 106 parents of toddlers $38(35.8 \%)$ had insufficient knowledge about the development of toddlers. The low level of knowledge of parents of children under five who were used as respondents in Balongrejo Village was due to many factors, such as their low education where their average level of education was not more than 9 years, lack of socialization or counseling conducted by local health workers because there were only 1 assigned health worker, namely a Village Midwife. In accordance with the theory that the level of parental education is very influential on the development of children. The low level of parental education is a risk for the delay in child development. This low education can affect knowledge and ability to provide less stimulation than mothers with higher levels of education. The level of education of parents, especially mothers, greatly influences their care for their children, healthy behavior, education and so on (Ariani and Yosoprawoto, 2013).

From the results of the statistical test it can be seen that knowledge does not affect the development of toddlers with a sig value $=0.996$ or greater than the value of $\alpha=0.05(\mathrm{P}>\alpha)$. The results of this study contradict the results of research from Christiari and Kusuma (2013) which state that maternal knowledge about child development and shows a positive and significant relationship with the 
development of children under five. The higher the mother's knowledge about the development of toddlers, and the provision of psychosocial stimulation in infants, the development of toddlers is getting better too. Parents especially mothers as the closest caregivers of a child must know more about the child's development process and the factors that influence the process. The formation of a child's quality is strongly influenced by the understanding, awareness and ability of the mother in handling children.

Parents who live in rural areas with knowledge that is less likely to be difficult to accept new things as well as health problems for toddlers, require repeated counseling so that they can accept something or something new about health education. Good knowledge so parents can receive all information from outside, especially about how to care for a good child, how to maintain children's health, education and so on. The better the knowledge, the younger a person receives information and is more responsive to the problems at hand, so that he can determine the best alternative to something as well as the developmental problems of toddlers (Safitri, 2017).

\section{Development of toddlers in families PBI BPJS participants in Balongrejo Village, Bagor District, Nganjuk Regency}

From this study, it can be concluded that almost $51(48.2 \%)$ of 106 children in Balongrejo village in the BPJS PBI families sampled experienced developmental problems, $22(20.8 \%)$ had dubious development and $29(27.4 \%)$. has a deviant development. The number of toddlers in Indonesia is around $10 \%$ of the entire population of children. So as a candidate for the next generation, the quality of toddler growth in Indonesia needs serious attention. In 2007 around 35.4\% of children under five in Indonesia suffered from developmental deviations such as gross motor aberrations, fine motor skills, and mental emotional deviations. In 2008 based on monitoring the growth and development status of infants, the prevalence of growth and growth dropped to $23.1 \%$. This is due to Indonesia's progress in the education program (Imelda, 2017).

Ability development above there are several characteristics of the development aspects in it, namely motoric, cognitive, and language development. Motor development can be assessed from the ability to eat / drink alone, dress alone, wash hands / feet alone, and defecate / splash themselves. For cognitive and language development can be assessed from the ability to recognize the names of parts of his own body, know the names of his own family members, know the time, and can recognize household furniture.

Communication / speaking is the type of aspect that has the most delays in this study. To achieve good development many factors that influence it in general can be influenced by several factors, namely internal and external factors. Internal factors include gender, infectious disease, immunization, nutritional status, energy and protein intake and external factors including the level of family income, maternal education level, parental employment status, and feeding patterns for toddlers (Moonik, Lestari and Wilar, 2015).

The results of the partial analysis of the influence of nutritional status, food intake, history of infectious diseases and knowledge of toddler development found that only nutritional status and food intake had an effect on development, then the results of further analysis simultaneously only nutritional status that influences the development of infants with nutritional status a good 1.8 times can have the opportunity to improve the development process of toddlers. If parents provide appropriate nutritional intake for children so that it affects children's nutritional status for the better. This good nutritional status finally has a good impact on the development of children's abilities.

The results of this study are supported by research from Rohimah (2015) which states that there is a dominant influence between nutritional status and development of toddlers. Child development has its own stages according to the age of the child. Children who cannot reach the development stage that are in accordance with their age are usually children from families with low socioeconomic status with poor nutritional status. 


\section{CONCLUSION}

Based on the results of research and discussion, it can be concluded as follows:

Nutritional Status $19(19 \%)$ of $106(100 \%)$ toddlers in BPJS PBI family members in Balongrejo Village, Bagor District, Nganjuk Regency, poor and Nutritional Status 27 (25.5\%) of $106(100 \%)$ children in BPJS participating families PBI in Balongrejo Village, Bagor District, Nganjuk District is lacking

Food intake $35(33 \%)$ of $106(100 \%)$ toddlers in the PBJ BPJS family in Balongrejo Village, Bagor Subdistrict, Nganjuk Regency is lacking 28 (26.4\%) of 106 (100\%) children in PBI BPJS families in Balongrejo Village, Bagor District, Nganjuk Regency, have a history of infectious diseases 38 (35.8\%) of 106 (100\%) knowledge about toddlers in PBI BPJS family members in Balongrejo Village, Bagor District, Nganjuk District

The development of 29 (27.4\%) of $106(100 \%)$ toddlers in the PBI BPJS family in Balongrejo Village, Bagor District, Nganjuk Regency deviated and Development of 22 (27.4\%) of $106(100 \%)$ children in BPJS participant families PBI in Balongrejo Village, Bagor District, Nganjuk Regency is doubtful

Statistical test results using Ordinal Regression obtained on the nutritional status variable Sig. (2-tailed) $=0,000<0,05$, then $\mathrm{H} 0$ is rejected. This means that $\mathrm{H} 1$ can be accepted between nutritional status and the development of toddlers

Statistical test results using Ordinal Regression obtained in the variable intake of food Sig. (2-tailed) $=0,000<0,05$, then $\mathrm{H} 0$ is rejected. This means that $\mathrm{H} 1$ can be accepted between food intake and the development of toddlers

Statistical test results using Ordinal Regression obtained from infectious disease research variables Sig. $(2$-tailed) $=0.148>0.05$, then $\mathrm{H} 0$ is accepted. This means $\mathrm{H} 1$ is rejected so there is no difference between infection and development of toddlers

Statistical tests by using Regression obtained in the knowledge variable obtained by toddlers Sig. (2-tailed) $=0.996>0.05$, then $\mathrm{H} 0$ is accepted. This means $\mathrm{H} 1$ is rejected. So there is no difference between the knowledge of toddlers and the development of toddlers

Statistical test results between nutritional status variables, food intake, infectious disease statistics and developmental development using Ordinal Regression obtaining values on nutritional status variables are the most debated variables for the development of children with good nutritional status 1.3 times can have the opportunity to improve the development process of toddlers.

\section{SUGGEST}

\section{For Midwifery Professionals}

Health workers, especially midwives, are expected to be able to help students provide counseling and provide an understanding of nutritional status, food intake, history of infectious diseases and parents' knowledge to improve the development of children under five.

\section{For Respondents}

From the results of the research, especially parents of toddlers must increase food intake that is well-nourished and orderly and by providing a good stimulus to improve the development of toddlers.

\section{For Research Sites}

It is better if the Village Devices / Local Community Leaders conduct counseling or counseling to the community regarding how nutritional status, food intake, health and knowledge are used to improve the development of children under five. 


\section{For the community}

It is expected to provide care to toddlers in the form of increasing food intake, health status and parental education to improve toddler development.

\section{For Further Researchers}

The results of this study can be used as references for further researchers to conduct research and prove the influence of immunization disease history and parental knowledge on the development of toddlers

\section{REFERENCES}

Adi, A. C., \& Andrias, D. R. 2013, Balita pada Rumahatangga Miskin di Kabupaten Prioritas Kerawanan Pangan di Indonesia Lebih Rentan Mengalami Gangguan Gizi. In Child Poverty and Social Protection Conference. SMERU Research Institute.

Ariani, A., \& Yosoprawoto, M.2013, Usia anak dan pendidikan ibu sebagai faktor risiko gangguan perkembangan anak, Jurnal Kedokteran Brawijaya, 27(2), 118-121.

Badan Pusat Statistik. 2017, Depkes RI Survay Demografi dan Kesehatan Indonesia, Jakarta: BPS.

Dian, I.F., Eva, C., \& Rima, I. 2014, Hubungan Pemberian ASI dengan Tumbuh Kembang Bayi Umur 6 Bulan di Puskesmas Nanggalo, Jurnal Kesehatan Andalas, 5(2).

Dinas Kesehatan Provinsi Jatim. 2016, Profil Kesehatan Provinsi Jawa Timur Tahun 2016, Surabaya: Dinas Kesehatan Provinsi Jawa Timur.

2017, Profil Kesehatan Provinsi Jawa Timur Tahun 2017,

Surabaya: Dinas Kesehatan Provinsi Jawa Timur

Imelda, I. 2017, Pengetahuan Ibu Tentang Pemberian Stimulasi Dan Perkembangan Anak Pra Sekolah (3-5 Tahun) Di Banda Aceh, Idea Nursing Journal, 8(3).

Kemenkes RI. 2015, Profil Kesehatan Indonesia, Jakarta: Kemenkes RI

Moonik, P., Lestari, H., \& Wilar, R. 2015, Faktor-Faktor Yang Mempengaruhi Keterlambatan Perkembangan Anak Taman Kanak-Kanak, e-CliniC, 3(1).

Nurwijayanti, N. 2016, Keterkaitan Kekurangan Energi Protein (KEP) Dengan Kejadian Infeksi Saluran Pernafasan Akut (Ispa) Pada Balita Usia (1-5 Tahun). Care: Jurnal Ilmiah Ilmu Kesehatan, 4(3), 30-36.

Rohimah, E., Kustiyah, L., \& Hernawati, N.2015, Pola konsumsi, status kesehatan dan hubungannya dengan status gizi dan perkembangan balita, Jurnal Gizi dan Pangan, 10(2).

Safitri, Y. 2017, Faktor-faktor yang berhubungan dengan Perkembangan bahasa balita di UPTD kesehatan Baserah Tahun 2016, Jurnal Obsesi, Jurnal Pendidikan Anak Usia Dini, 1(2), 148155 .

Sandjaja Bee, K.L., Nipa, R., Bao, K.L.N., Basuki, B., Lai, O.N., Kusol, S., Hoang, T.X., Paul, D., dan Panam, P. 2013, Relationship between anthropometric indicators and cognitive performance in Southeast Asian school-aged children, British Journal of Nutrition, Vol. 110, : $557-564$ 
Sulistyorini, E., \& Rahayu, T. 2017, Hubungan Pekerjaan ibu balita terhadap status gizi balita di Posyandu Prima Sejahtera Desa Pandean Kecamatan Ngemplak Kabupaten Boyolali Tahun 2009, Jurnal Kebidanan Indonesia: Journal of Indonesia Midwifery, 1(2).

Solihin, R. D. M., Anwar, F., \& Sukandar, D. 2013, Kaitan antara status gizi, perkembangan kognitif, dan perkembangan motorik pada anak usia prasekolah (relationship between nutritional status, cognitive development, and motor development in preschool children), Penelitian Gizi dan Makanan, The Journal of Nutrition and Food Research, 36(1), 62-72 